STUDIES IN

L A N G U A G E

COMPANION

SERIES $\quad 77$

\title{
Case, Valency \\ and Transitivity
}

\author{
Edited by \\ Leonid Kulikov \\ Andrej Malchukov \\ Peter de Swart
}




\section{Studies in Language Companion Series (SLCS)}

The SLCS series has been established as a companion series to Studies in Language, International Journal, sponsored by the Foundation "Foundations of Language".

\section{Series Editors}

Werner Abraham

University of Vienna

\section{Editorial Board}

Joan Bybee

University of New Mexico

Ulrike Claudi

University of Cologne

Bernard Comrie

Max Planck Institute

For Evolutionary Anthropology, Leipzig

William Croft

University of New Mexico

Östen Dahl

University of Stockholm

Gerrit Dimmendaal

University of Leiden

Ekkehard König

Free University of Berlin

\author{
Michael Noonan \\ University of Wisconsin, Milwaukee
}

\author{
Christian Lehmann \\ University of Erfurt \\ Robert Longacre \\ University of Texas, Arlington \\ Brian MacWhinney \\ Carnegie-Mellon University \\ Marianne Mithun \\ University of California, Santa Barbara \\ Edith Moravcsik \\ University of Wisconsin, Milwaukee \\ Masayoshi Shibatani \\ Rice University and Kobe University \\ Russell Tomlin \\ University of Oregon
}

\section{Volume 77}

Case, Valency and Transitivity

Edited by Leonid Kulikov, Andrej Malchukov and Peter de Swart 


\section{Case, Valency and Transitivity}

Edited by

Leonid Kulikov

Leiden University

Andrej Malchukov

Peter de Swart

Radboud University Nijmegen

John Benjamins Publishing Company

Amsterdam/Philadelphia 
The paper used in this publication meets the minimum requirements of American National Standard for Information Sciences - Permanence of Paper for Printed Library Materials, ANsI z39.48-1984.

\section{Library of Congress Cataloging-in-Publication Data}

Case, Valency and Transitivity / edited by Leonid Kulikov, Andrej Malchukov and Peter de Swart.

77)

p. cm. (Studies in Language Companion Series, ISSN 0165-7763; v.

Includes bibliographical references and indexes.

1. Grammar, Comparative and general--Case. 2. Grammar,

Comparative and general--Transitivity. 3. Dependency grammar. 4.

Semantics. I. Kulikov, L.I. II. Mal'chukov, A.L. (Andrei L'vovich). III.

Swart, Peter de. IV. Series.

P240.6.C37 2006

$415.5--\mathrm{dc} 22$

2006040572

ISBN 9027230870 (Hb; alk. paper)

(C) 2006 - John Benjamins B.V.

No part of this book may be reproduced in any form, by print, photoprint, microfilm, or any other means, without written permission from the publisher.

John Benjamins Publishing Co. · P.O. Box 36224 1020 ME Amsterdam · The Netherlands John Benjamins North America · P.O. Box 27519 · Philadelphia PA 19118-0519 • USA 


\section{Table of contents}

Introduction

vii

Part I. Morphological case

1. Syntactic vs. morphological case: Implications for morphosyntax Andrew Spencer

2. Case systems in a diachronic perspective: A typological sketch Leonid Kulikov

3. Emergence of morphological cases in South Mande: From the amorphous type to inflectional?

Valentin Vydrine

4. Issues of morphological ergativity in the Tsimshian languages:

Agreement, determiners and the reconstruction of case

Tyler Peterson

5. Direction marking and case in Menominee Jochen Trommer

Part II. Case marking and transitivity: The syntax of case

6. Bare and prepositional differential case marking:

The exotic case of German (and Icelandic) among all of Germanic

Werner Abraham

7. Control infinitives and case in Germanic: 'Performance error' or marginally acceptable constructions?

Jóhanna Barðdal and Thórhallur Eythórsson

8. Experiencer coding in Nakh-Daghestanian

Dmitry Ganenkov

9. 'Argument-sharing' in Oriya serial verb constructions

Kalyanamalini Sahoo

Case marking and transitivity: Case interpretation

10. Two approaches to specificity

Lars Johanson

11. Case markedness

Peter de Swart 
12. Incremental distinguishability of subject and object 269 Helen de Hoop and Monique Lamers

Case marking and transitivity: Case and the typology of transitivity

13. The woman showed the baby to her sister: On resolving humanness-driven ambiguity in ditransitives Seppo Kittilä

14. Case semantics and the agent-patient opposition Ashild Ness

15. Transitivity parameters and transitivity alternations:

Constraining co-variation

Andrej Malchukov

16. Transitivity in Songhay Julia Galiamina

Part III. Transitivity and valency change

17. Syntactic valence, information structure, and passive constructions in Kaqchikel

George Aaron Broadwell

18. A very active passive: Functional similarities between passive and causative in Balkar

Ekaterina Lyutikova and Anastasia Bonch-Osmolovskaya

19. Case marking, possession and syntactic hierarchies

in Khakas causative constructions in comparison with other Turkic languages

Alexander Letuchiy

20. Transitivity increase markers interacting with verb semantics:

Evidence from Finno-Ugric languages

Elena Kalinina, Dmitriy Kolomatsky, Alexandra Sudobina

21. Extraversive transitivization in Yucatec Maya

and the nature of the applicative

Christian Lehmann and Elisabeth Verhoeven

Language index

Subject index 